[解説]

墓地 の 判 読

\title{
Interpretation of Area Good for Cemetery
}

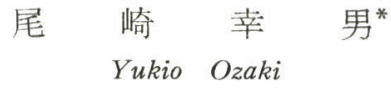

写真判読については種々報告や論文も出されている が，いずれも専門的な内容のものが多いようなので, 時節外れながら肩のこらない墓場さがしの話を紹介し たい。

\section{$\langle$ その I $\rangle$}

デルフトのI T Cを訪ねられた方はご存知の筈だが デルフト駅から I T Cに行く運河沿いの道の右側に 1 部こんもりとした小高い緑地がある。これが実は墓地 であって，空堀に囲まれて一見小公園の上うに見党 る。

ところでョーロッパでは土葬の習慣がかなり残って いるそうであるが，都市計画等のための慕地移転等で 新しい墓地をさがす時にこれが問題になるとのことで ある。限られた幕地にあとからあとからと新らしい埋 葬をする以上，いずれは前に埋めた場所へも束た埋め な计ればならなくなる。その時に以前の遺体が出て来 るよらでは困る。従って適当な期間で遺体が分解して
土に帰るような土地でないと土葬用の墓地としては適 当でない。このための条件の 1 つとして地下水位が埋 葬の深さよりも深く, 遣体が水浸けにならないことが 必要である。これは遣体が空気にふれて次第に酸化分 解して行く状態でな计ればならないからであるが， 一 方あまり酸化が早く進んでも困る。

それで結局地上水位が一定の深度でなけ札ばならな いことになる。この地下水位の深度を地表の写真の状 態 (作物の種類, 樹朴の成育状況, 土の色や濃度等) から判定して候補地を探すのだそらである。勿論写真 判読だけで水位を正確に知ることはできないので，判 読によって候補地を党らび出した上，現地でボーリン グ等によってさらにくわしく調査し，最終的な決定を 下寸のである。

これ以上あまりくわしく聞けなかったのは残念であ る。日本でも墓地の選定等に今後このようにして写真 判読を利用することが考えられる。

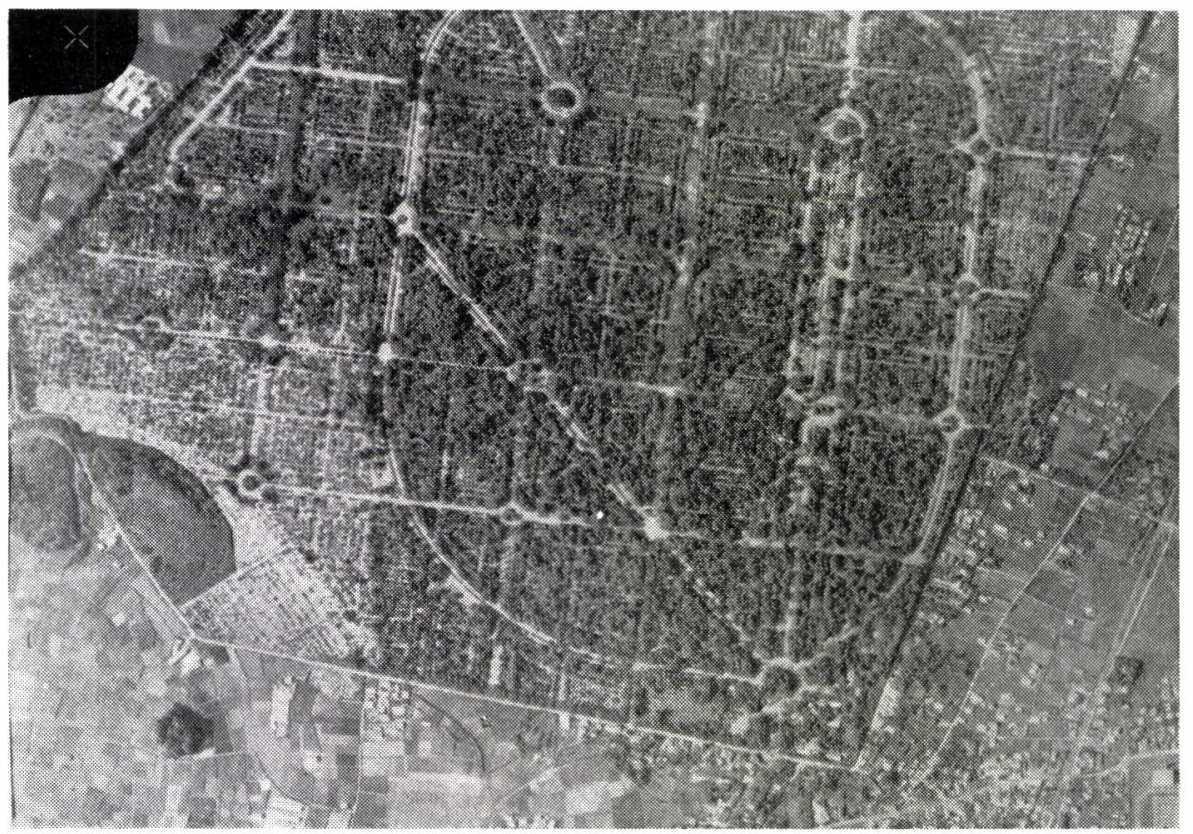

* 国土地理院 写真測量 VOL. 5 No. 2 1966年 


\section{〈そのII〉}

縦貫自動車道の写真地戝を作る場合, 墓地や祠等は なるべく詳しく入れたいとの注文を受けた。墓は文字 通り墳墓の地であり, 神社や祠の上らな信仰の対象之 共に補償や撤去・移転の際に特別の配虑が必要だから である。

これが機縁となって筆者は茥地判読に関心を持つよ らになり，今ではひそかに墓地さがしのオーリリティ を以て任じているが，果して実際の役に立つかどらか は䂑問である。だが写真地質や森林判読とちがって墓 地学の専門家というのは多分いないと思われるので勝 手にオーソリティと自称しているだけであるが，あえ て墓地判読の大略をのベると次のよらにもなろらか。

まず写真縮尺は $1 / 2$ 万〜 I/1万程度がの年まい。 $1 / 2$ 万以下では幕地発見は飛躍的に困難になるよらに 思われる。

最後のきめ手は実体視である。1/1万〜 $1 / 2$ 万の写真 では個々の墓石を確実に見ることはできないが，針尖 か羽毛の屑の上らに見之る微小な墓石がチカチカと光 っているよらな感じを受ける。墓不が十数個以上群を なしている場合はかなり高い確率で墓地を発見するこ とができるが，数個以下の場合は相当難しい。また多 摩霊園（第1図，第 2 図）の上らに大きいものは公園 のようにも見えるが, 内部の道路配置や実体視によっ て簡単に:園と区別することがでさる。

第 1 図の実体空中写真と第 2 図の斜め写真とを比較
しながらよく確かめられたい。

しかし小さい墓地の発見はかなり困難なのでま・ナ゙墓 地のありそらな個所の見当をつけて, それから実体視 によって判読して行く方が有效であらう。

この見当をつけるのは常識的な推理による他はな い。即ら

A 人間の住んでいるかぎり埋葬の必要性が生ずる

B 遠くに埋葬することは困難だが，逆に部落の真 中に埋葬することもない

C 従って部落の周辺乃至少し難れた所に埋葬地が 必ずある笘である。

このことは「野辺の送り」という諺の通りであって

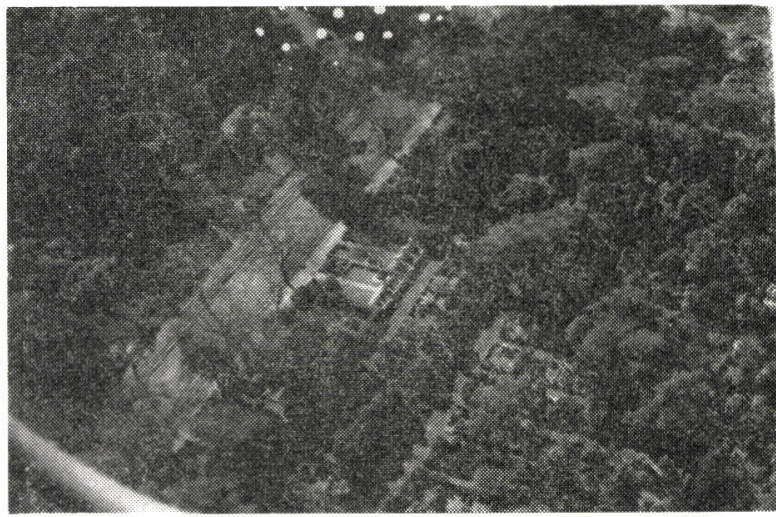

第 2 図 多 摩 霊 園

斜写真

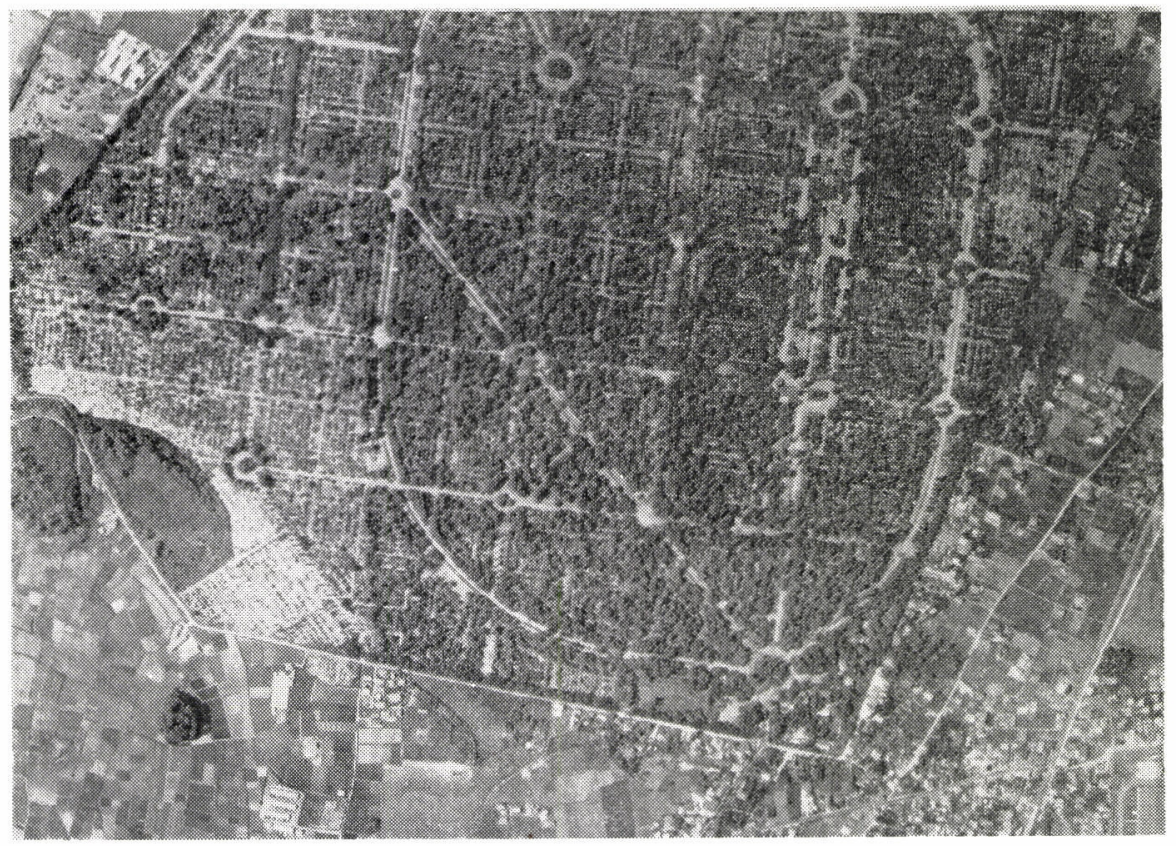

第1図多摩霊 園

縮尺 約 $1 / 10,000$ 
なお次のようなことがらがキーとして判読の助けにな る。

(1) 火葬の習慣の地方では墓地の一隅に必ず火葬場 がある。従って部落外に一劃の草地があってその 一隅に小建築物が 1 軒ある場合, 墓地である公算 が大きい。（第6因参照）

(2) 墓地の大きさは部落の大きさや古さと相関があ る。しかし墓地は一部落に一個所とは限らないか ら注意を要する。逆に大きい部落周辺で小さい墓 地を一つ発見した場合は, 他にもないかと一㐫探 して見る心゙きであろら。

(3) 莫地に利用されるのは農地として不適当な侗所 例えば山腹や河原近くのことが多いが，概して低 地よりは小高い場所に多い。

（4）墓地の近くには寺があることが多い。あるいは 寺の近くに墓地があるといった方がもしろ適切か も知れないが。

（5）墓地は「方位」に関する信仰から部落の北方乃 至東北方向にあることが多い。

このよらにしてまず広範囲の探査区域から子備知識 や資料によって可能性のある地区をし滦り, さらにく わしく判読して行く。これはもっと複雑な各種の判読 のプロセスの模型とも言え判読の小手調べ，あるいは 判読実習としては手頃な課題ではないかと考えられ
る。最初は地図上で墓地をさがし, その位置を空中写 真上で確梕寸るか，あるいは既に現地を見て知ってい る墓地を写真上で見つけることから始めるのが順序で あるら。

第 3 図と第 4 図は墓地写真の例で, 第 5 戍は第 4 図

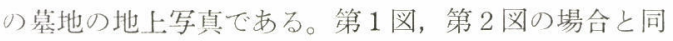
椂に比較参照されたい。第 6 図は小墓地 (火葬小屋を伴う) の例である。

これらの墓地の写真は実体写真刘としてあるが，印 刷の際網版をかけるので実体視して果してどの程度ま で墓石が判読できるか疑開である。機会があれば印刷 していないなまの密着真写あるいは引伸写真によって 実体感を確かめていただきたい。

ここに例としてあげたのは大きい墓地が多いが，小 さい莫地は判読が困難な5え, 上述のように，印刷の 網版のせいも西って, 判読できるかどらか疑りしい。 これも折があれば实際の写真について確かめられた い。

ここでは第 6 図が小墓地の例であるが，この写真の 中央附近の小居が火葬小屋で，火葬小屋を含息一割が 墓地である。原写真上でも判読は非常に困難であった が，1/5万地形闵上の墓地記号から火葬小屋をキーと して写真上で確認できた例である。

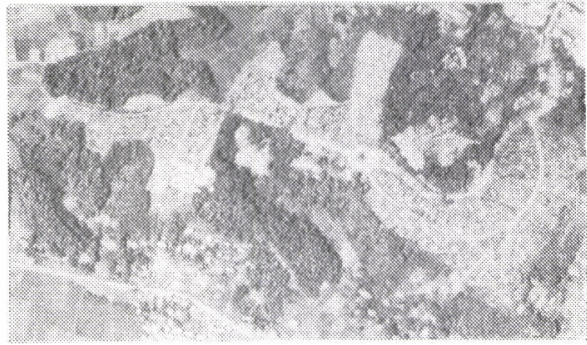

第 3 図 墓

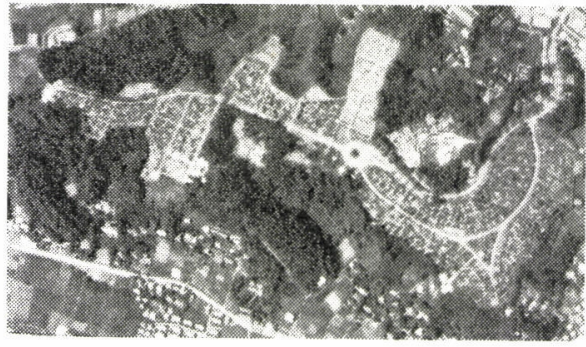

縮尺 $1 / 10,000$

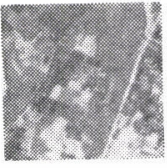

第6図 小墓 地 (一宮付近)

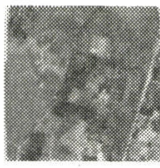

縮尺約 $1 / 15000$ (原縮尺約 $1 / 20,000$ ) 


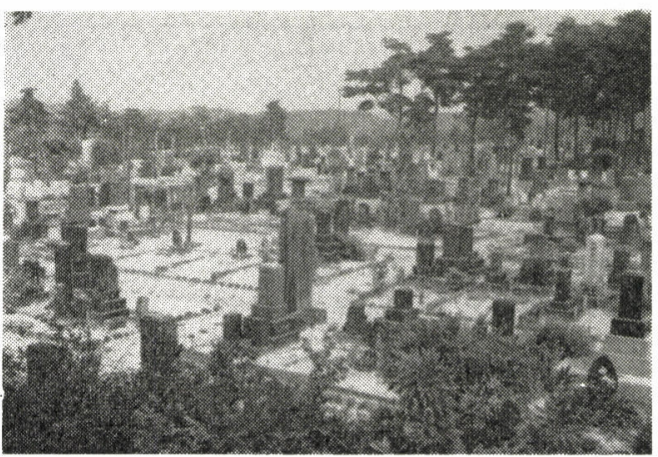

第 5 図 墓 地（仙台市）

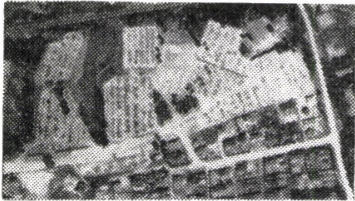

第4図墓地（仙台市）

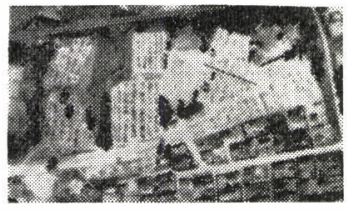

縮尺約 $1 / 18.000$

地上写真

\section{〈写真測量関係の単行本〉}

(1)

会員から時折照会があるので，講夾ものも加之年 代順にまとめ, こらめぐさ、とした。落ち, 誤り等 あれば御一報されたい。

(中村貢治調)

$*$

1. 鈴木猶吉著 $>$ 写真測量: 昭和 6 年 岩波書店》岩波講座地理学》

2 . 石井英滳著 $>$ 地籍測量 $=$ 昭和 9 年 岩波書店

3 . 丹波長道著 航空写真: 昭和10年 木本氏房著 “写真測量、 誠文堂新光社 》最新写真科学大系心

4. 林 猛雄著“航空写真測量、昭和10年 シビル社 再刊コロナ社

5 . 丹波長道著 ‘航空写真: 昭和12年 共立社 $、$ 写真科学講座》

6.シュヴィデフスキー著・武田通治訳 空中地上

写真測量、昭和14年 古今書院

7. 木本氏房著》航空写真測量、昭和16年 満州航空株式会社

8. 理研科学映画株編 “空中写真測量、昭和17年 科学主義工業社

9. 小本氏房著 “航空測量、昭和 20 年 白水社 、科学選書心

10. 篠 邦彦著 ‘写真測量法概論、昭和 23 年 旧日本写真測量学会
11. 武田通治著 “空中写真測量の乎引、 昭和 24 年 旧日本写真測量学会

12. 佐藤 久著 “空中写真に上る土地調査と写真判 読、昭和 25 年

旧日本写真測量学会

13. 武田通治著 $>$ 写真測量 $邓$ 昭和 26 年 オーム社 ‘測量技術講座ミ

14. 武田通治著》図解射線法の実際、昭和28年 旧日本写真測量学会 再刊日本測量協会

15. 小本氏房著》航空写真測量、昭和 32 年 日本林業技術協会

16. フォン・ラーエル著・户部厚滋訳 ‘森林写真測 量概要 $、$ 昭和32年

日本林業技術協会

17. 日林協測量指導部編 “空中写真測量 基準 カー ドミ 昭和 34 年

日本林業技術協会

18. 片岡秀夫著 “近代的森林調査法の実務、昭和 34 年旦本林業調查会

19. 木本氏尋著 “航空写真測量の実際、昭和34年 日本測量協会

20，尾崎幸男著 “写真測量 $=$ 昭和 34 年 森北出版社、測量実務叢書心

21. 日林協測量指尊部編 “空中写真判読 比較 カー ドミ 昭和 35 年

日本林業技術協会

22. 高橋三郎 - 森本久弥著 “写真測量と地図編集の 問題、昭和 36 年

日本測量協会 